\title{
Effect of elevated atmospheric carbon dioxide on the allelopathic potential of common ragweed
}

\author{
Jichul Bae ${ }^{1,5+}$, Chaeho Byun ${ }^{2 \dagger}$, Yun Gyong Ahn ${ }^{3}$, Jung Hyun Choi ${ }^{4}$, Dowon Lee ${ }^{1}$ and Hojeong Kang ${ }^{2,6^{*}}$
}

\begin{abstract}
Background: Allelopathy has been suggested as one potential mechanism facilitating the successful colonisation and expansion of invasive plants. The impacts of the ongoing elevation in atmospheric carbon dioxide $\left(\mathrm{CO}_{2}\right)$ on the production of allelochemicals by invasive species are of great importance because they play a potential role in promoting biological invasion at the global scale. Common ragweed (Ambrosia artemisiifolia var. elatior), one of the most notorious invasive exotic plant species, was used to assess changes in foliar mono- and sesquiterpene production in response to $\mathrm{CO}_{2}$ elevation ( $389.12 \pm 2.55$ vs. $802.08 \pm 2.69$ ppm).

Results: The plant growth of common ragweed significantly increased in elevated $\mathrm{CO}_{2}$. The major monoterpenes in the essential oil extracted from common ragweed leaves were $\beta$-myrcene, DL-limonene and 1,3,6-octatriene, and the major sesquiterpenes were $\beta$-caryophyllene and germacrene-D. The concentrations of 1,3,6-octatriene (258\%) and $\beta$-caryophyllene (421\%) significantly increased with $\mathrm{CO}_{2}$ elevation.

Conclusions: These findings improve our understanding of how allelochemicals in common ragweed respond to $\mathrm{CO}_{2}$ elevation.
\end{abstract}

Keywords: Allelopathy, Ambrosia artemisiffolia var. elatior, Monoterpene, Sesquiterpene, $\mathrm{CO}_{2}$ elevation

\section{Background}

Invasive exotic plants are recognised as one of the biggest threats to native ecosystems because they outcompete native species and alter environmental conditions and resource availability (D'Antonio and Vitousek 1992). Native to North America, common ragweed (Ambrosia artemisiifolia var. elatior L.) is rapidly spreading across many parts of East Asia (Chen et al. 2007; Fang and Wan 2009; Kil et al. 2004; Miyawaki and Washitani 2004; Xu et al. 2006), Europe (Bullock et al. 2010; Essl et al. 2015; Smith et al. 2013) and Australia (Bass et al. 2000), where it becomes invasive and poses a threat to agroecosystems, native ecosystems and public health. In South Korea, common ragweed is designated as one of

\footnotetext{
* Correspondence: hj_kang@yonsei.ac.kr

${ }^{\dagger}$ Jichul Bae and Chaeho Byun contributed equally to this work.

${ }^{2}$ School of Civil and Environmental Engineering, Yonsei University, Seoul 03722, Republic of Korea

${ }^{6}$ School of Civil and Environmental Engineering, Yonsei University, N303

Yonsei-ro 50, Seodaemun-gu, Seoul 03722, Republic of Korea

Full list of author information is available at the end of the article
}

the 14 most problematic invasive alien plants by the Act on the Conservation and Use of Biodiversity, the Ministry of Environment.

The allelopathic effect of plant terpenoids is of great ecological interest as many plant species enhance their competitiveness and fitness through allelopathy. The Novel Weapon hypothesis proposed by Callaway and Ridenour (2004) attributes the successful establishment and proliferation of some invasive exotic plants in introduced ranges to their allelochemicals (Callaway and Ridenour 2004). Although these chemicals are relatively ineffective against neighbours in the native range of the invasive species due to co-evolved tolerance, these substances can act as 'novel weapons' when encountered by adjacent plant species in invaded ranges (Callaway and Aschehoug 2000; Callaway and Ridenour 2004). Allelopathic effects of invasive plant terpenoids on the germination and growth of native and crop species in invaded ranges have been observed in numerous cases, demonstrating that allelopathy plays a potential role in the success of some invasive exotic plants (Barney et al. 2005; 
Cipollini and Dorning 2008; Ens et al. 2009a; Ens et al. 2009b; Kong et al. 2007; Maharjan et al. 2010; Orr et al. 2005; Prati and Bossdorf 2004; Sun et al. 2006; Tefera 2002; Wang et al. 2010; Yamamoto 1995; Zhao et al. 2009). Most volatile and reactive terpenes such as monoand sesquiterpenes are usually stored in leaves, and these compounds induce allelopathic effects on neighbouring plants through leaf volatilisation or leachates.

Allelopathy has been suggested as a possible mechanism underlying the successful introduction and establishment of invasive exotic plant species in new habitats because allelochemicals released from an invader are often evolutionarily novel to a recipient native community (Callaway and Ridenour 2004; Hierro and Callaway 2003). Volatile oils of common ragweed are allelochemicals released into the environment through leaf volatilisation or leachates that can affect the growth and other functions of nearby flora (Beres et al. 2002; Chalchat et al. 2004; Fischer and Quijano 1985; Pajević et al. 2010). Vidotto et al. (2013) demonstrated that leaf residues of common ragweed inhibit early growth of crop species including tomato and lettuce, as well as germination of weed species such as large crabgrass (Digitaria sanguinalis). Choi et al. (2010) reported that an extract from common ragweed leaves inhibits germination and seedling growth of various weed species including barnyard grass (Echinochloa crus-galli), large crabgrass (D. sanguinalis) and Asian flatsedge (Cyperus microiria). A bioassay study showed that the allelopathic effect of common ragweed leaf extract was stronger than that of flower and achene extracts (Kazinczi et al. 2008a, 2008b). By contrast, Kazinczi et al. 2008a, 2008b demonstrated that leaf extracts of sunflower (Helianthus annuus), field bindweed (Convolvulus arvensis) and velvetleaf (Abutilon theophrasti) promoted rather than inhibited germination and growth of common ragweed, and found that common ragweed could utilise these extracts as a source of nutrients. Additionally, no autotoxicity of common ragweed extracts was observed in their studies (Kazinczi et al. 2008a, 2008b). Therefore, allelopathic effects may provide common ragweed with a competitive advantage over the neighbouring plant community and may play a role in facilitating its successful invasion and proliferation in newly invaded habitats.

Global mean atmospheric carbon dioxide $\left(\mathrm{CO}_{2}\right)$ has increased by $29 \%$ since preindustrial times and is anticipated to reach 600 to $1000 \mathrm{ppm}$ by the year 2100 (Pachauri et al. 2014). Rising $\mathrm{CO}_{2}$ mixing ratio in the atmosphere is responsible for climate change and has widespread impacts on terrestrial biology. Due to its threats to native ecosystems and public health, specific attention has been given to determine the role of rising atmospheric $\mathrm{CO}_{2}$ mixing ratio with respect to the distribution, growth and pollen production of common ragweed
(Bullock et al. 2010; Essl et al. 2015; Hamaoui-Laguel et al. 2015; Rogers et al. 2006; Smith et al. 2013; Ziska and Caulfield 2000). However, no information is currently available concerning the impact of rising $\mathrm{CO}_{2}$ mixing ratio on the allelopathic potential of this species. Elevated atmospheric $\mathrm{CO}_{2}$ mixing ratio increases carbon (C) supply and thus leads to high $\mathrm{C} / \mathrm{N}$ ratios in plant tissues, eventually making conditions favourable for the production of C-based secondary compounds (Bazin et al. 2002; Berenbaum 1995; Bryant et al. 1983; Coley et al. 1985; Coviella et al. 2002; Peñuelas and Estiarte 1998; Raisanen et al. 2008; Stamp 2003). However, the effects of elevated atmospheric $\mathrm{CO}_{2}$ mixing ratio on the production of allelochemicals affecting the invasiveness of plants have not been widely studied (Applebee et al. 1999; Lindroth 1996).

Understanding the physiology and ecology of common ragweed in response to environmental change is of great importance because this species poses a major threat to public health, native ecosystems and agroeconomy in many parts of the world. Previous studies showed that global environmental changes such as elevated $\mathrm{CO}_{2}$ mixing ratio and global warming can promote the growth and allergenic pollen production of common ragweed (Hirose et al. 1996; Ziska et al. 2007; Ziska and Caulfield 2000).

Carbon-based substances such as mono- and sesquiterpenes are the prominent components of volatile allelochemicals derived from common ragweed leaves (Chalchat et al. 2004). Therefore, we hypothesised that elevated $\mathrm{CO}_{2}$ mixing ratio concentrations would increase foliar monoand sesquiterpene production in this species.

\section{Materials and methods}

\section{Growth chamber}

Growth chambers $\left(140 \times 74 \times 1200 \mathrm{~cm}^{3}\right.$, DS-51GLP, Dasol Science, Republic of Korea) with different target $\mathrm{CO}_{2}$ mixing ratio concentrations (400 and $800 \mathrm{ppm}$ ) were used for $\mathrm{CO}_{2}$ mixing ratio manipulation experiments. Chambers were programmed with an alternating day/night temperature regime of $28 / 22^{\circ} \mathrm{C}$, a $14 / 10 \mathrm{~h}$ day/night photoperiod and relative humidity of $60 \%$. The light intensity was 148.5 PPFD $\left(\mu \mathrm{mol} / \mathrm{m}^{2} / \mathrm{s}\right)$, and the dawn and dusk transitions lasted $1 \mathrm{~h}$. The $\mathrm{CO}_{2}$ mixing ratio concentration in the chamber was lowered by incoming air from the laboratory in which the $\mathrm{CO}_{2}$ mixing ratio concentration was higher than $430 \mathrm{ppm}$; therefore, $\mathrm{CO}_{2}$ mixing ratio absorbent (SODASORB, Grace Darex Packaging Technologies, USA) was applied to achieve the target ambient $\mathrm{CO}_{2}$ mixing ratio concentration. To minimise any absorbent-specific effects, the same amount of $\mathrm{CO}_{2}$ absorbent was also applied for the target elevated $\mathrm{CO}_{2}$ mixing ratio condition. The $\mathrm{CO}_{2}$ mixing ratio conditions for both the ambient $(389.12 \pm 2.55 \mathrm{ppm})$ and elevated $(802.08 \pm 2.69 \mathrm{ppm})$ atmospheres during the 
experimental period (60 days) were maintained by applying $500 \mathrm{~g}$ of absorbent and replacing it every 5 days.

\section{Seed collection and plant propagation}

Common ragweed involucral achenes (hereafter referred to as seeds) were extracted from soil samples collected along agriculture field edges infested with the species in Heungeop-ri, Heungeop-myeon, Wonju-si, Gangwon-do, South Korea (latitude $37.18^{\circ} \mathrm{N}$, longitude $127.54^{\circ} \mathrm{E}$ ) in April 2009. We had to moisten the seeds of common ragweed before sowing seeds because their seeds are highly dormant (Baskin and Baskin 1980). Common ragweed seeds need cold-wet stratification period lasting for 2-4 weeks. A total of 100 randomly chosen seeds were placed on two layers of Whatman No. 2 filter paper (Whatman International Ltd.) moistened with $5 \mathrm{~mL}$ of distilled water in four Petri dishes (25 seeds per dish). Dishes were placed in the growth chamber under ambient $\mathrm{CO}_{2}$ mixing ratio conditions. Following the 7-day germination period, 48 seedlings of similar height $(3-5 \mathrm{~cm})$ were planted into twelve 3-L pots (four seedlings per pot) filled with a standard potting mixture containing peat moss, decomposed organic soil, sand, vermiculate and perlite at a ratio of 2:2:2:1:1 $(\mathrm{v} / \mathrm{v})$. Pots were randomly assigned to the two growth chambers (six pots per chamber). Four plants in each pot were thinned to one plant per pot at the six to eight leaf stage in order to ensure uniformity among the plants. In this way, shading effect on neighbouring plant was prevented. The selected plants were grown for 60 days, and pots were randomly rearranged within the chamber weekly to minimise location-specific effects. Shading by neighbouring plants was not observed during the experiments. The entire experiment was repeated 12 times.

\section{Growth analysis}

After 60 days of growth, growth analysis was performed.

\section{Allelochemical extraction and analysis}

After 60 days of growth, all leaves were separated from the stem and $\sim 3 \mathrm{~g}$ of fresh leaves from each plant was manually ground at room temperature with sea sand (15-20 mesh) and $40 \mathrm{~mL}$ of $\mathrm{n}$-pentane. Each sample was then spiked with $1 \mathrm{~mL}$ of $0.1 \%$ tetradecane as an internal standard. The resulting extract was filtered through a Whatman No. 40 filter paper cone (Whatman International Ltd.) with sodium sulphate and concentrated by evaporation with a gentle stream of nitrogen gas. Extracts were stored in sealed vials at $-20^{\circ} \mathrm{C}$ until chemical analysis.

Gas chromatography/mass spectrometry (GC/MS) analysis was performed using an Agilent 6890 Plus gas chromatograph equipped with a 5973-N quadrupole mass selective detector (Palo Alto, CA, USA). Using a
DB-5 MS capillary column $(30 \mathrm{~m} \times 0.25 \mathrm{~mm}$ i.d., $0.25 \mu \mathrm{m}$ film thickness, $5 \%$ diphenyl:95\% dimethylsiloxane phase, J\&W Scientific, Folsom, CA, USA), the GC oven was maintained at $60^{\circ} \mathrm{C}$ for $2 \mathrm{~min}$ then elevated to $310^{\circ} \mathrm{C}$ in increments of $5{ }^{\circ} \mathrm{C} / \mathrm{min}$ and maintained at that temperature for $2 \mathrm{~min}$. The sample was injected at a split ratio of 1:10. The temperature of the GC injection port and the MS interface was $250^{\circ} \mathrm{C}$ and $280^{\circ} \mathrm{C}$, respectively. The mass selective detector was run in electron impact (EI) mode with an electron energy of $70 \mathrm{eV}$. The mass spectrometer was operated in full scan mode between 50 and $700 \mathrm{amu}$. The Wiley7n spectra database was used for compound identification.

The internal standard yielded a peak with a retention time ranging from 19.26 to $19.46 \mathrm{~min}$. The identity of each compound was confirmed by determining the retention time and comparing with mass spectral data in publicly available databases $(\geq 90 \%$ representing a positive identification). To investigate the effects of $\mathrm{CO}_{2}$ mixing ratio on the number of mono- and sesquiterpenes produced, the detection frequency with which each individual compound was observed in each treatment was measured. The area of the internal standard peak and those of mono- and sesquiterpenes in the GC chromatograms were calculated, and their ratios were then used to measure the concentrations of the analytes.

\section{Statistical analysis}

Data collected from chemical analyses were averaged for each treatment. One-way analysis of variance (ANOVA) was used to investigate the effects of $\mathrm{CO}_{2}$ mixing ratio on allelochemical content. All analyses in the present study were conducted with JMP version 8 (SAS Institute Inc., Cary, NC, USA 2008).

\section{Results}

Growth of common ragweed (number of leaves, aboveground height, fresh weight) significantly increased in elevated $\mathrm{CO}_{2}$ compared to ambient $\mathrm{CO}_{2}$ condition (Table 1). The retention time and detection frequency of individual mono- and sesquiterpenes are shown in Table 2. The major mono- and sesquiterpenes (those most abundant and present in all extract samples) included three monoterpenes ( $\beta$-myrcene, DL-limonene

Table 1 Growth of common ragweed (number of leaves, aboveground height, fresh weight) in ambient $\mathrm{CO}_{2}$ treatment and elevated $\mathrm{CO}_{2}$ treatment

\begin{tabular}{llll}
\hline & \multicolumn{2}{l}{$\mathrm{CO}_{2}$ treatment } & $P$ value \\
\cline { 2 - 3 } & Ambient & Elevated & \\
\hline No. of leaves & $35.5 \pm 3.5$ & $45.0 \pm 1.8$ & 0.02577 \\
Aboveground height $(\mathrm{mm})$ & $246.3 \pm 10.3$ & $345.8 \pm 26.5$ & 0.00205 \\
Fresh weight $(\mathrm{g})$ & $4.6 \pm 0.3$ & $6.1 \pm 0.5$ & 0.02276 \\
\hline
\end{tabular}


Table 2 Retention time, relative frequency and relative abundance of identified mono- and sesquiterpenes in essential oil from $A$. artemisiifolia var. elatior leaves

\begin{tabular}{|c|c|c|c|c|c|}
\hline \multicolumn{3}{|l|}{ Monoterpenes } & \multicolumn{3}{|l|}{ Sesquiterpenes } \\
\hline Compounds & R.T. & D.F. (\%) & Compounds & R.T. & D.F. (\%) \\
\hline 2-Hexenal & 4.56 & 88 & Bicycloelemene & 17.51 & 21 \\
\hline Santolina triene & 5.57 & 63 & $\delta$-Elemene & 17.59 & 46 \\
\hline a-Pinene & 6.40 & 96 & a-Copaene & 18.69 & 38 \\
\hline Camphene & 6.82 & 4 & $\beta$-Bourbonene & 18.92 & 13 \\
\hline Sabinene & 7.39 & 29 & $\beta$-Elemene & 19.04 & 38 \\
\hline$\beta$-Pinene & 7.54 & 83 & $\beta$-Caryophyllene & 19.88 & 100 \\
\hline$\beta$-Myrcene & 7.78 & 100 & $\gamma$-Elemene & 20.06 & 33 \\
\hline DL-Limonene & 8.93 & 100 & $\beta$-Cubebene & 20.11 & 4 \\
\hline 1,3,6-Octatriene & 9.37 & 100 & Bergamotene & 20.14 & 83 \\
\hline Chrysanthenone & 11.58 & 33 & $\gamma$-Cadinene & 20.47 & 8 \\
\hline \multirow[t]{14}{*}{ Borneol } & 13.06 & 25 & $\beta$-Farnesene & 20.60 & 33 \\
\hline & & & $\beta$-Selinene & 20.76 & 8 \\
\hline & & & a-Caryophyllene & 20.79 & 92 \\
\hline & & & a-Selinene & 21.19 & 25 \\
\hline & & & $\gamma$-Curcumene & 21.27 & 17 \\
\hline & & & Germacrene-D & 21.43 & 100 \\
\hline & & & Aromadendrene & 21.61 & 17 \\
\hline & & & Bicyclogermacrene & 21.76 & 88 \\
\hline & & & $\delta$-Cadinene & 22.28 & 29 \\
\hline & & & $\beta$-Sesquiphellandrene & 22.40 & 4 \\
\hline & & & a-Gurjunene & 22.63 & 4 \\
\hline & & & Elemol & 23.00 & 4 \\
\hline & & & Germacrene B & 23.31 & 46 \\
\hline & & & endo-1-Bourbonanol & 23.71 & 42 \\
\hline
\end{tabular}

R.T. retention time $(\mathrm{min})$, D.F. detection frequency (presented as percentage occurrence in all extract samples)

and 1,3,6-octatriene) and two sesquiterpenes ( $\beta$-caryophyllene and germacrene-D; Table 2).

The results demonstrated that elevation in $\mathrm{CO}_{2}$ mixing ratio concentration significantly influenced the relative concentrations of the major mono- and sesquiterpenes (Fig. 1). The relative concentrations of the major mono- and sesquiterpenes increased in conjunction with $\mathrm{CO}_{2}$ elevation as follows: $\beta$-myrcene (203\%), DL-limonene (105\%), 1,3,6-octatriene (258\%), $\beta$-caryophyllene (421\%) and germacrene-D (138\%).

\section{Discussion}

The main foliar mono- and sesquiterpenes identified in the present study included three monoterpenes ( $\beta$-myrcene, DL-limonene and 1,3,6-octatriene) and two sesquiterpenes ( $\beta$-caryophyllene and germacrene-D), consistent with previous investigations. Chalchat et al. (2004) reported that the main components of essential oils obtained from common ragweed shoots by steam distillation were germacrene-D (24.1\%), DL-limonene (16.8\%), $\alpha$-pinene (8.0\%), $\beta$-myrcene (7.4\%) and borneol (2.9\%) (Chalchat et al. 2004). Similarly, Kim and Kim (1999) found octene (15.67\%), 1,3,6-octatriene (15.00\%), $\beta$-myrcene (12.98\%), borneol (10.30\%) and $\alpha$-pinene (3.21\%) to be the most abundant monoterpenes in essential oils from common ragweed leaves (Peñuelas and Llusià 1997). However, the proportion of major essential oil components in the present study was considerably less than in previous studies. This apparent discrepancy may result from the fact that Chalchat et al. (2004) analysed essential oil from steam distillation of $100 \mathrm{~g}$ of dried flowering shoots rather than $4 \mathrm{~g}$ of fresh young leaves in the current study. Moreover, Chalchat et al. (2004) analysed flowering shoots of common ragweed in September, and Kim and Kim (1999) averaged the amount of foliar monoterpenes from late March to September, whereas 60-day-old leaves were used in the present study, resulting in smaller amounts of allelochemicals. Peñuelas and Llusià (1997) suggested that the concentration of volatile terpenes in plants is influenced by environmental factors such as seasonality (larger content in autumn) and age (larger content in older plants). Indeed, Kim and Kim (1999) observed a seasonal variation: the total monoterpene concentration in ragweed leaves increased continuously from a plastochron index of 2.0 (early spring) to 11.89 (immediately prior to flowering).

The ecological effectiveness of allelopathy is concentration-dependent (Lotina-Hennsen and King-Diaz 2005); therefore, changes in the concentration of allelochemicals in response to environmental or habitat conditions determine the degree to which these compounds are exposed to neighbouring plants, and hence their allelopathic potential. Environmental stresses such as elevated atmospheric $\mathrm{CO}_{2}$ mixing ratio may enhance the allelopathic potential of plants (Anaya 1999). The current study showed that increased $\mathrm{C}$ supply (i.e., elevated $\mathrm{CO}_{2}$ mixing ratio) increased the relative concentrations of major mono- and sesquiterpenes. The degree to which changes in $\mathrm{CO}_{2}$ mixing ratio influenced each major mono- or sesquiterpene was variable and dependent on the type of compound. These compounds may have differing biosynthetic origins and thus respond differently to environmental variables. It would be worthwhile examining the magnitude of the responses to elevated $\mathrm{CO}_{2}$ mixing ratio in terms of differences in their structures and synthetic mechanisms (i.e., expression of genes encoding synthase enzymes for each compound) in future studies.

Although a single population approach and experiments in controlled environments such as growth chambers can have some limitations when attempting to draw general conclusions, the findings of the present study improve our understanding of how the invasiveness of common ragweed is induced by 

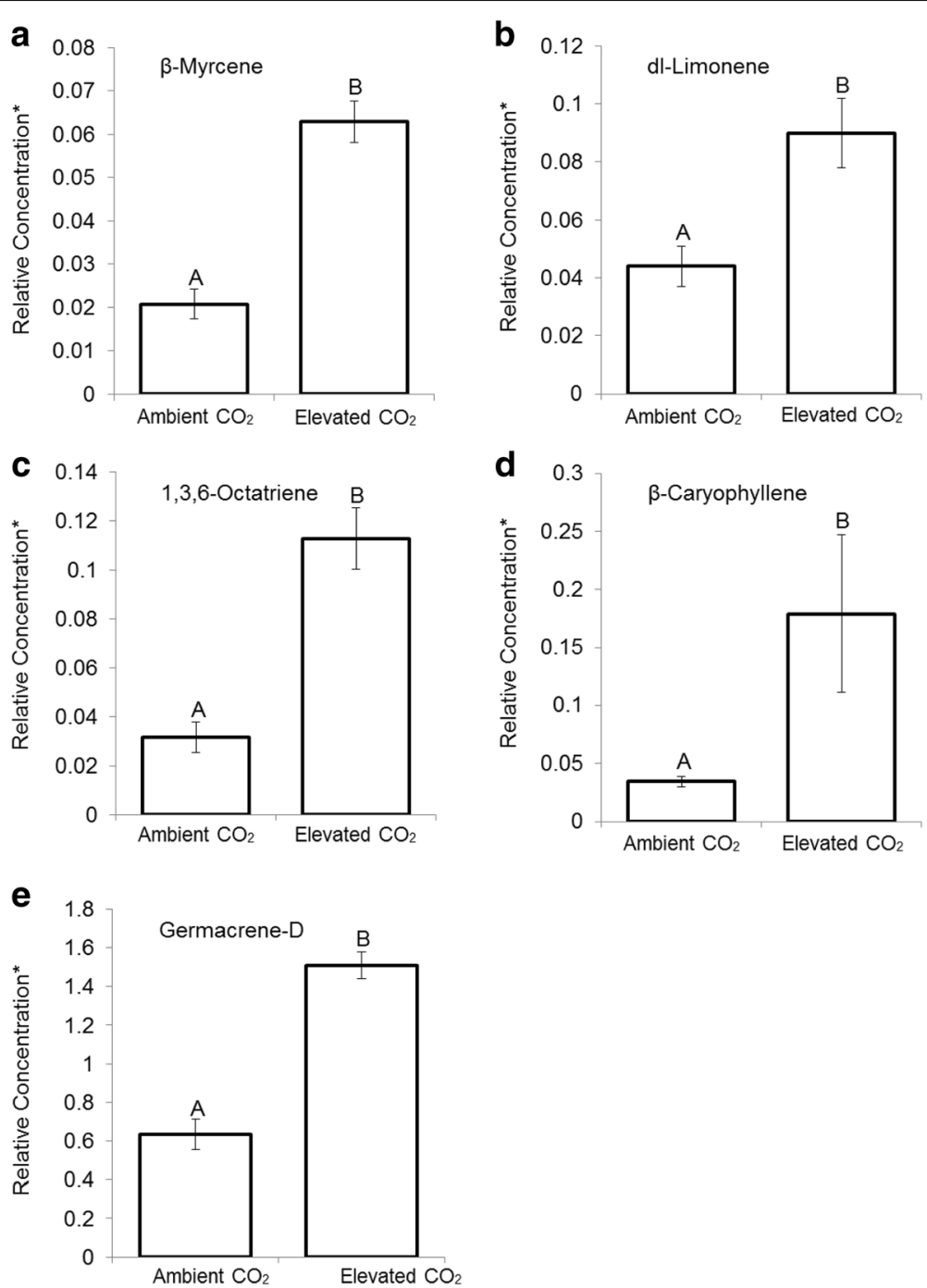

Fig. 1 Relative concentrations of major mono- and sesquiterpenes of A. artemisiifolia var. elatior in response to ambient ( $389 \pm 2.55 \mathrm{ppm})$ and elevated $(802 \pm 2.69 \mathrm{ppm}) \mathrm{CO}_{2}$ treatment. The effects of $\mathrm{CO}_{2}$ on the relative concentration of a $\beta$-myrcene, $\mathbf{b} \mathrm{DL}$-limonene, $\mathbf{c} 1,3,6$-octatriene, d $\beta$-caryophyllene and $\mathbf{e}$ germacrene- $D$ were determined. Asterisk denotes that relative concentration was obtained from the ratio of the peak area of the analyte to that of the internal standard. Values are means \pm standard error. Bars not connected by the same letter are significantly different $(p<0.05)$

allelochemicals and how elevated $\mathrm{CO}_{2}$ mixing ratio can affect this process. We want to emphasise that elevated $\mathrm{CO}_{2}$ increases alleochemicals of common ragweed and it may be one of many possible reasons that common ragweed is highly invasive these days.

\section{Conclusion}

We have experimentally proven that elevated $\mathrm{CO}_{2}$ can increase the growth and the concentrations of alleochemicals in common ragweed which is one of most well-known invasive plants. The relative concentrations of the major monoterpenes ( $\beta$-myrcene 203\%, DL-limonene $105 \%$, and $1,3,6$-Octatriene $258 \%$ ) and sesquiterpenes ( $\beta$-caryophyllene $421 \%$ and germacrene-D 138\%) increased in conjunction with $\mathrm{CO}_{2}$ elevation. Our finding indicated that one of the key mechanisms connecting elevated $\mathrm{CO}_{2}$ and plant invasiveness is alleochemicals. We suggest the following studies on the effect of increased $\mathrm{CO}_{2}$ on alleochemicals using other invasive plants in different environment to generalise our finding.

\section{Nomenclature}

Common ragweed, Ambrosia artemisiifolia var. elatior

\section{Acknowledgements}

The authors would like to acknowledge Dr. Samsik Kang (College of Pharmacy, Seoul National University) and Dr. Jonghee Kim (Department of Biology, Gyeongnam University) for the technical advice and supportive 
discussion and Dr. Changsuk Kim (National Institute of Agricultural Science and Technology) for the seed collection. This work has been supported by the National Research Foundation of Korea (NRF) grant funded by the Korea government (MSIT)(2018R1C1B6005351). We are grateful to NRF (2016R1D1A1A02937049, 2017096A001719BB01) for the financial support.

\section{Availability of data and materials}

All relevant data are available from the Figshare database (https:/figshare.com/ articles/Common_ragweed_allelopathy_allelochemical_data/6337004/1).

\section{Authors' contributions}

$\mathrm{JB}$ carried out the experiment and data analysis and wrote the draft of the manuscript. CB wrote the draft of the manuscript and revised the manuscript. YA assisted in the data analysis. JC assisted in the data analysis. $\mathrm{DL}$ conceived the concept of this paper and revised the manuscript. HK revised the manuscript. All authors read and approved the final manuscript.

\section{Ethics approval and consent to participate}

Not applicable

\section{Consent for publication}

Not applicable

\section{Competing interests}

The authors declare that they have no competing interests.

\section{Publisher's Note}

Springer Nature remains neutral with regard to jurisdictional claims in published maps and institutional affiliations.

\section{Author details}

'Department of Environmental Planning, Graduate School of Environmental Studies, Seoul National University, Seoul 151-742, Republic of Korea. ${ }^{2}$ School of Civil and Environmental Engineering, Yonsei University, Seoul 03722, Republic of Korea. ${ }^{3}$ Korea Basic Science Institute, Seoul Center, Seoul, Republic of Korea. ${ }^{4}$ Department of Environmental Science and Engineering, Ewha Womans University, Seoul 120-750, Republic of Korea. ${ }^{5}$ Current Address: Agassiz Research and Development Centre, Agriculture and Agri-Food Canada, Agassiz, BC VOM 1A0, Canada. ${ }^{6}$ School of Civil and Environmental Engineering, Yonsei University, N303 Yonsei-ro 50, Seodaemun-gu, Seoul 03722, Republic of Korea.

\section{Received: 6 December 2018 Accepted: 16 April 2019}

Published online: 22 May 2019

\section{References}

Anaya AL. Allelopathy as a tool in the management of biotic resources in agroecosystems. Cr Rev Plant Sci. 1999;18(6):697-739.

Applebee TA, Gibson DJ, Newman JA. Elevated atmospheric carbon dioxide alters the effects of allelochemicals produced by tall fescue on alfalfa seedlings. Trans III State Acad Sci. 1999;92:23-31.

Barney JN, Hay AG, Weston LA. Isolation and characterization of allelopathic volatiles from mugwort (Artemisia vulgaris). J Chem Ecol. 2005;31(2):247-65.

Baskin JM, Baskin CC. Ecophysiology of secondary dormancy in seeds of Ambrosia artemisiifolia. Ecology. 1980;61(3):475-80.

Bass DJ, Delpech V, Beard J, Bass P, Walls RS. Ragweed in Australia. Aerobiologia. 2000;16(1):107-11.

Bazin A, Goverde M, Erhardt A, Shykoff JA. Influence of atmospheric carbon dioxide enrichment on induced response and growth compensation after herbivore damage in Lotus corniculatus. Ecol Entomol. 2002;27(3):271-8.

Berenbaum MR. The chemistry of defense: theory and practice. Proc Natl Acad Sci U S A. 1995;92(1):2-8.

Beres I, Kazinczi G, Narwal S. Allelopathic plants. 4. Common ragweed (Ambrosia elatior L. Syn A. artemisiifolia). Allelopathy J. 2002;9(1):27-34.

Bryant JP, Chapin FS III, Klein DR. Carbon/nutrient balance of boreal plants in relation to vertebrate herbivory. Oikos. 1983;40(3):357-68.

Bullock J, Chapman D, Schafer S, Roy D, Haynes T, Beal S, Wheeler B, Dickie I, Phang Z, Tinch $R$, et al. Assessing and controlling the spread and the effects of common ragweed in Europe. In: European Commision. Final report: ENV. B2/ETU/2010/0037; 2010. p. 456
Callaway RM, Aschehoug ET. Invasive plants versus their new and old neighbors: a mechanism for exotic invasion. Science. 2000;290(5491):521-3.

Callaway RM, Ridenour WM. Novel weapons: invasive success and the evolution of increased competitive ability. Front Ecol Environ. 2004;2(8):436-43.

Chalchat J-C, Maksimovic Z, Petrovic S, Gorunovic M, Dordevic S, Mraovic M. Chemical composition and antimicrobial activity of Ambrosia artemisiifolia L. essential oil. J Essent Oil Res. 2004;16:270-3.

Chen $\mathrm{H}$, Chen L, Albright T Developing habitat-suitability maps of invasive ragweed (Ambrosia artemisiifolia. L) in China using GIS and statistical methods. In GIS for health and the environment: development in the AsiaPacific region with 110 figures. Edited by Lai P, Mak A. Heidelberg: Springer Berlin Heidelberg; 2007: 105-121.

Choi B, Song D, Kim C, Song B, Woo S, Lee C. Allelpathic effects of common ragweed (Ambrosia artemisifolia var. elatior) on the germination and seedling growth of crops and weeds. Korean J Weed Sci. 2010;30(1):34-42.

Cipollini D, Dorning M. Direct and indirect effects of conditioned soils and tissue extracts of the invasive shrub, Lonicera maackii, on target plant performance. Castanea. 2008;73(3):166-76.

Coley P, Bryant J, Chapin F III. Resource availability and plant antiherbivore defense. Science. 1985;230(4728):895-9.

Coviella CE, Stipanovic RD, Trumble JT. Plant allocation to defensive compounds: interactions between elevated $\mathrm{CO}_{2}$ and nitrogen in transgenic cotton plants. J Exp Bot. 2002;53(367):323-31.

D'Antonio C, Vitousek P. Biological invasions by exotic grasses, the grass/fire cycle, and global change. Annu Rev Ecol Syst. 1992;23(1):63-87.

Ens EJ, Bremner JB, French K, Korth J. Identification of volatile compounds released by roots of an invasive plant, bitou bush (Chrysanthemoides monilifera spp. rotundata), and their inhibition of native seedling growth. Biol Invasions. 2009a; 11(2):275-87.

Ens EJ, French K, Bremner JB. Evidence for allelopathy as a mechanism of community composition change by an invasive exotic shrub, Chrysanthemoides monilifera spp. rotundata. Plant Soil. 2009b;316(1): 125-37.

Essl F, Biró K, Brandes D, Broennimann O, Bullock J, Chapman D, Chauvel B, Dullinger S, Fumanal B, Guisan A, et al. Biological flora of the British Isles: Ambrosia artemisiffolia. J Ecol. 2015;103(4):1069-98.

Fang J, Wan F. Invasive species and their impacts on endemic ecosystems in China. In: Kohli R, Jose S, Singh H, Batish D, Boca Raton FL, editors. Invasive plants and forest ecosystem. USA: CRC Press; 2009. p. 157-76.

Fischer N, Quijano L. Allelopathic agents from common weeds:Amaranthus palmeri, Ambrosia artemisiifolia, and related weeds, pp. 133-147, in A.C. Thompson (ed.). The Chemistry of Allelopathy: Biochemical Interactions Among Plants. ACS Symposium Series No. 268. Washington, D.C: American Chemical Society; 1985.

Hamaoui-Laguel L, Vautard R, Liu L, Solmon F, Viovy N, Khvorostyanov D, Essl F, Chuine I, Colette A, Semenov M, et al. Effects of climate change and seed dispersal on airborne ragweed pollen loads in Europe. Nature Clim Change. 2015;5(8):766-71.

Hierro JL, Callaway RM. Allelopathy and exotic plant invasion. Plant Soil. 2003; 256(1):29-39.

Hirose T, Ackerly DD, Traw MB, Bazzaz FA. Effects of $\mathrm{CO}_{2}$ elevation on canopy development in the stands of two co-occurring annuals. Oecologia. 1996; 108(2):215-23.

Kazinczi G, Béres I, Novák R, Bíró K, Pathy Z. Common ragweed (Ambrosia artemisiifolia): a review with special regards to the results in Hungary. I. Taxonomy, origin and distribution, morphology, life cycle and reproduction strategy. Herbologia. 2008a;9(1):55-91.

Kazinczi G, Béres I, Onofri A, Nádasy E, Takács A, Horváth J, Torma M. Allelopathic effects of plant extracts on common ragweed (Ambrosia artemisiifolia L.). J Plant Dis Prot. 2008b;21:335-40.

Kil J, Shim K, Park S, Koh K, Suh M, Ku Y, Suh S, Oh H, Kong H. Distributions of naturalized alien plants in South Korea. Weed Technol. 2004;18:1493-5.

Kim J-H, Kim H-S. Variation Monoterpenes during Leaf Development in Ambrosia artemisiifolia var. elatior. J Ecol Environ 1999;22(3):155-61.

Kong $\mathrm{CH}$, Wang P, Xu XH. Allelopathic interference of Ambrosia trifida with wheat (Triticum aestivum). Agri Ecosyst Environ. 2007;119(3-4):416-20.

Lindroth RL. Consequences of elevated atmospheric CO2. Carbon dioxide, populations, and communities; 1996. p. 347.

Lotina-Hennsen B, King-Diaz B, Terrones Hernandez MG Plant secondary metabolites. Targets and mechanisms of allelopathy. In Allelopathy: a physiological process with ecological implications. Edited by Reigosa MJ, Pedrol N, González L. Netherlands: Springer; 2005. p. 230-231. 
Maharjan S, Shrestha BB, Jha PK. Allelopathic effects of aqueous extract of leaves of Parthenium Hysterophorus L. on seed germination and seedling growth of some cultivated and wild herbaceous species. Sci World. 2010;5(5):33-9.

Miyawaki S, Washitani I. Invasive alien plant species in riparian areas of Japan: the contribution of agricultural weeds, revegetation species and aquacultural species. Global Environmental Research. 2004;8(1):89-101.

Orr SP, Rudgers JA, Clay K. Invasive plants can inhibit native tree seedlings: testing potential allelopathic mechanisms. Plant Ecol. 2005;181(2):153-65.

Pachauri RK, Allen MR, Barros VR, Broome J, Cramer W, Christ R, Church JA, Clarke L, Dahe Q, Dasgupta P. Climate change 2014: synthesis report. Contribution of Working Groups I, II and III to the fifth assessment report of the Intergovernmental Panel on Climate Change: IPCC; 2014.

Pajević S, Borišev M, Orčić D, Boža P, Nikolić N. Photosynthetic and biochemical characteristics of invasive species (Ambrosia artemisiifolia L., Ambrosia trifida L. and Iva xanthifolia Nutt.) depending on soil humidity and phenological phase. Russian J Ecol. 2010;41(6):498-505.

Peñuelas J, Estiarte M. Can elevated $\mathrm{CO}_{2}$ affect secondary metabolism and ecosystem function? Trends Ecol Evol. 1998;13(1):20-4.

Peñuelas J, Llusià J. Effects of carbon dioxide, water supply, and seasonality on terpene content and emission by Rosmarinus officinalis. J Chem Ecol. 1997; 23(4):979-93.

Prati D, Bossdorf O. Allelopathic inhibition of germination by Alliaria petiolata (Brassicaceae). Am J Bot. 2004;91(2):285-8.

Raisanen T, Ryyppo A, Julkunen-Tiitto R, Kellomaki S. Effects of elevated $\mathrm{CO}_{2}$ and temperature on secondary compounds in the needles of Scots pine (Pinus sylvestris L.). Trees-Struct Funct. 2008;22(1):121-35.

Rogers C, Wayne P, Macklin E, Muilenberg M, Wagner C, Epstein P, Bazzaz F. Interaction of the onset of spring and elevated atmospheric $\mathrm{CO}_{2}$ on ragweed (Ambrosia artemisiifolia L.) pollen production. Environ Health Perspect. 2006;114(6):865-9.

Smith M, Cecchi L, Skjøth C, Karrer G, Šikoparija B. Common ragweed: a threat to environmental health in Europe. Environ Int. 2013;61:115-26.

Stamp N. Out of the quagmire of plant defense hypotheses. Q Rev Biol. 2003; 78(1):23-55.

Sun B, Tan J, Wan Z, Gu F, Zhu M. Allelopathic effects of extracts from Solidago canadensis L. against seed germination and seedling growth of some plants. J Environ Sci. 2006:18(2):304-9.

Tefera T. Allelopathic effects of Parthenium hysterophorus extracts on seed germination and seedling growth of Eragrostis tef. J Agron Crop Sci. 2002; 188(5):306-10.

Vidotto F, Tesio F, Ferrero A. Allelopathic effects of Ambrosia artemisiifolia L. in the invasive process. Crop Prot. 2013;54:161-7.

Wang RL, Staehelin C, Peng SL, Wang WT, Xie XM, Lu HN. Responses of Mikania micrantha, an invasive weed to elevated $\mathrm{CO} 2$ : induction of $\beta$-caryophyllene synthase, changes in emission capability and allelopathic potential of $\beta$ Caryophyllene. J Chem Ecol. 2010;36(10):1076-82.

Xu H, Qiang S, Han Z, Guo J, Huang Z, Sun H, He S, Ding H, Wu H, Wan F. The status and causes of alien species invasion in China. Biodivers Conserv. 2006; 15(9):2893-904

Yamamoto Y. Allelopathic potential of Anthoxanthum odoratum for invading Zoysia-grassland in Japan. J Chem Ecol. 1995;21(9):1365-73.

Zhao X, Zheng GW, Niu XM, Li WQ, Wang FS, Li SH. Terpenes from Eupatorium adenophorum and their allelopathic effects on Arabidopsis seeds germination. J Agric Food Chem. 2009;57(2):478-82.

Ziska L, George K, Frenz D. Establishment and persistence of common ragweed (Ambrosia artemisiifolia L.) in disturbed soil as a function of an urban-rural macro environment. Glob Chang Biol. 2007;13(1):266-74

Ziska $\mathrm{LH}$, Caulfield FA. Rising $\mathrm{CO}_{2}$ and pollen production of common ragweed (Ambrosia artemisiifolia), a known allergy-inducing species: implications for public health. Aust J Plant Physiol. 2000;27(10):893-8.

Ready to submit your research? Choose BMC and benefit from:

- fast, convenient online submission

- thorough peer review by experienced researchers in your field

- rapid publication on acceptance

- support for research data, including large and complex data types

- gold Open Access which fosters wider collaboration and increased citations

- maximum visibility for your research: over $100 \mathrm{M}$ website views per year

At $\mathrm{BMC}$, research is always in progress.

Learn more biomedcentral.com/submissions 